Pre-print de:

González-Álvarez, David (2019): Rethinking tourism narratives on the cultural landscapes of Asturias (Northern Spain) from the perspective of Landscape Archaeology: Do archaeologists have anything to say? Landscape Research, 44(2): 117-133. doi: https://doi.org/10.1080/01426397.2017.1413174

\title{
Rethinking tourism narratives on the cultural landscapes of Asturias (Northern Spain) from the perspective of Landscape Archaeology: do archaeologists have anything to say?
}

\author{
David González-Álvarez a,b * \\ ORCID: http://orcid.org/0000-0001-7021-9321 \\ ${ }^{\mathrm{a}}$ Institute of Heritage Sciences (Incipit), Spanish National Research \\ Council (CSIC), Santiago de Compostela, Spain; \\ ${ }^{b}$ Department of Archaeology, Durham University, Durham, UK \\ *e-mail: david.gonzalez-alvarez@incipit.csic.es
}

\begin{abstract}
:
As in other rural areas in Spain, the Asturian countryside suffers from a profound demographic and economic crisis. Since tourism emerged as one of the main hopes for the reactivation of rural economy, the regional government has made a particular effort in promoting rural tourism. This paper intends to assess the effects that naturalistic and atemporal narratives of Asturian landscapes exert on the rural farming communities, which define the 'tourism imaginaries' as they become established as identity referents not only for visitors, but for the inhabitants of the region themselves. Archaeology can enhance the local communities' agency through the appreciation of cultural values attached to these landscapes. To this end, the diachronic depth of the social and productive processes which shaped the Asturian landscapes is emphasised by relying on Landscape Archaeology. The relevant role played by farmers and herders in these activities merits their involvement in actively designing future policies.
\end{abstract}

Keywords: Landscape Archaeology; tourism imaginaries; landscapes diachrony; anthropisation; territorial branding

\section{Introduction}

Asturias is a small region located in the Western part of the Cantabrian Coast, on the North-west of Spain. For most people, this region features several good examples of natural landscapes in which to spend their holidays if a well-preserved and quiet rural setting in which to hike, sightsee or relax is sought. Tourism is an ever-increasing activity there (Valdés, Aza, \& Baños, 2010), and promoting it has been a priority for the regional government in the last few decades. Thirty years ago, the local government's promotion campaign was met with tremendous success. The slogan for promoting rural tourism was 'Asturias, Natural Paradise' (from the Spanish Asturias, Paraíso Natural), which is still in use. ${ }^{1}$

This successful slogan and the related campaigns constructed narratives which had a significant impact on the identity of rural communities in Asturias. In this paper, I will argue that these campaigns have questioned the agency of rural farming communities and even their dignity, since their relevance to landscape management through time has been undermined. Moreover, I will reflect on the commodification of the Asturian landscapes, endeavouring to connect Landscape Archaeology research with rural landscape management and tourism policies design. In so doing, I will emphasise that archaeologists - among other social scientists - should adopt 
a more proactive role in contemporary public discussions about the design of governance formulae. In fact, as social scientists, we may build cultural narratives on landscapes which could be used by subaltern stakeholders aiming to challenge public policies imposed from above, which underestimate the social and cultural aspects of landscapes while imposing a naturalistic point of view.

\section{2. 'Asturias, Natural Paradise'}

'Asturias, Natural Paradise' is the main slogan for tourism promotion in this region. In fact, it is the oldest tourism slogan still in use by an Autonomous Community in Spain, and it has become a sort of 'territorial brand' (Alameda \& Fernández, 2012; Plumed, 2014). The logo of this campaign constitutes a paradigmatic exponent for the tourism narratives behind it. This representation is very easily recognisable by the public, since it has never been modified [Figure 1]. It represents an idyllic rural vision of the Asturian landscape, with green meadows beneath high mountains next to the sea. The scene is framed between the arches of the early medieval palace of Santa María del Naranco in Oviedo, one of the pre-Romanic monuments declared by UNESCO as a World Heritage Site at the 9th Session of the Committee in $1985 .{ }^{2}$ This is the only reference to human presence in the whole illustration, and it is indeed a subtle one. As we look further into the picture, we can imagine herds of cattle grazing in the green landscape commonly associated with Asturias, yet the animals are not there, nor the people. Could this absence be fortuitous?

Since the aforementioned promotional campaign was launched, messages from the Asturian institutions and the regional tourism agencies have been strongly influenced by this sort of naturalistic and timeless approach. In this sense, rural landscapes in Asturias are valued in terms of their natural resources, and the lack of human footprints intruding on this natural state. Nature plays a predominant role in these promotions, focused on the magnificent peaks of the Cantabrian Mountains, on the thick oak and beech forests of the region, or on the small and paradisiacal beaches spread along the so-called 'Green Coast'. Consequently, it is not surprising that bears have become the main protagonists of tourism advertising [Figure 2(a)], with the inclusion of Hanna-Barbera cartoons from The Yogi Bear show as the most recent star guests of the Asturian tourism agency's official TV commercials [Figure 2(b)]. Meanwhile, the rural farming communities and the extensive cultural biography of these landscapes are silenced, as unwanted guests to these contemporary and ready-for-consumption representations [Figure 2(c)]. Beyond the radius of governmental tourism agencies, these naturalistic narratives are being naturalised at different levels in popular culture, as can readily be observed in cinema (e.g. Martínez-Expósito, 2014, p. 346-348) through films such as La Torre de Suso (2007) and ¿Para qué sirve un oso? (2011) directed by Tom Fernández, or Cenizas del cielo directed by José Antonio Quirós (2008).

Within that idyllic and naturalistic image of the Asturian rural landscape, only a few outstanding monuments, such as Palaeolithic caves containing rock art, some medieval churches or ethnographic buildings - the hórreos and paneras (traditional wooden elevated granaries) protrude among forests in the mountains or cliffs on the coast. However, tourism narratives conceive these elements in isolation to the cultural, economic and social contexts in which they are viewed by local communities. It is true that other cultural elements such as the bagpipe, the wooden clogs - commonly known as madreñas - or the art of cider pouring in the traditional Asturian way are also depicted. Yet, these cultural elements become commodified cultural representations disconnected from their social and productive contexts, as mere souvenirs or experiences for tourists (Comaroff \& Comaroff, 2009), revealing the 'McDisneyization' of tourism in post-modernity (Ritzer \& Liska, 1997).

Accordingly, most tourism campaigns about Asturias have firmly established a discourse focused on the natural components of its landscapes. For example, a recent complementary campaign 
to 'Asturias, Natural Paradise' was launched a few years ago, relying on the concept of 'Paradise keepers' (from Spanish Guardianes del paraíso). Who were those people? As archaeologists, we could affirm they should have been ancient people who lived in the area, or perhaps contemporary farmers, fishermen and shepherds, or even forest wardens, firemen and lumberjacks. However, it is mainly tourists wearing sport clothing and enjoying the sights that are portrayed. None of these Paradise keepers ever worked the land in a way that has enabled Asturias landscapes to become what they are nowadays [Figure 3]. Instead, those tourists are the consumers of 'natural and authentic experiences' (Wang, 1999) during their vacation time in Asturias, following the usual referents derived from marketing related to natural or rural tourism (Hellín, 2007).

Moreover, the message 'Asturias, Natural Paradise' is frequently linked to some of the most elite Asturian athletes, the main local football teams, as well as to outstanding sport events such as La Vuelta, an international cycling race which takes place in Spain. Due to the popularity of the campaign and its continuity throughout more than three decades, the slogan is now pretty familiar to most Asturian citizens. In fact, many people wear the 'Asturias, Natural Paradise' logo on their clothes or on stickers alongside their car plates. Therefore, I would argue that the 'Asturias, Natural Paradise' logo has become a kind of 'reference of prestige' or an identity symbol to many Asturian inhabitants and a clear referent for the visitors who come to this region. The success of this campaign has made an impression on the Asturian society itself, since it would seem that the local population have fully internalised the content of this campaign as a symbol. But at the same time, unfortunately, they might be assuming the simplistic 'tourism imaginaries' (Salazar, 2010, 2012) attached to this promotion, instead of recognising and celebrating the valuable human side of these landscapes.

In 2015, the 30th anniversary of the 'Asturias, Natural Paradise' campaign was celebrated ${ }^{3}$ and a drawing competition for children called 'That's how my natural paradise looks like' (from Spanish Así es mi paraíso natural) was organised. Thus, pupils from several schools within the region were encouraged to make drawings reflecting their view on the Asturian landscape, with 161 participants. The representations made by the children include mountains, forests and wild animals such as bears as the main elements in the landscape [Figure 4]. Meanwhile, human presence is reduced to stereotypical representations with people playing bagpipes or pouring cider in traditional costumes - sometimes, even with bears replacing farmers in the aforementioned situations. Additionally, we find few historical monuments or picturesque buildings, such as lighthouses, elevated granaries - the hórreos - or shepherds' huts with a thatched straw or broom roof - the teitos. However, when they are depicted, they appear isolated from productive activities - agriculture and herding - that give them full cultural meaning. The same panorama can be observed in another drawing competition organised in 2016 by Central Lechera Asturiana - the largest dairy company in the region - with the motto 'Asturias, Natural Paradise'. Exploring a selected gallery from one of the schools that took part in the contest, ${ }^{4}$ we are struck with the same impression. We can perceive a naturalistic and devoid-of-people view of Asturias which is being normalised amongst children in regards to the nature of their homeland landscapes; meanwhile the temporality of the landscape and the anthropogenic impact on it are absent, and the human presence is reduced to normalised cultural representations to be observed and experienced by people unconnected to those scenes. These situations emphasise the need to disseminate a more complex view among Asturian children regarding the landscape biographies of their region, aiming to avoid the reproduction of atemporal and naturalistic tourism imaginaries as their only references for conceptualising Asturian landscapes.

We can safely deduce, therefore, that the inculcation in the Asturian population of a presentist and naturalistic vision on their own landscape has been undeniably successful. Despite these nature-focused narratives, it is well-established that the current appearance of the rural landscapes in Europe is the result of complex and diachronic processes of human activity, as long demonstrated by social scientists (Hirsch \& O'Hanlon, 1995; Ingold, 2000; Johnson, 2007; 
Sauer, 1925). Thus, we can stress that several cultural, social, political and economic factors are - in addition to environmental aspects - essential to understanding the roots and the biography of cultural landscapes. Therefore, it follows that the Asturian 'natural paradise' is actually an artificial misleading image in which the cultural aspects should bear a more significant weight. In fact, it has become a postmodern cultural representation which, with regard to its origins in a tourism context, could be considered as a paradigmatic example of a successful experience in the construction of tourism imaginaries. This process is not an isolated example, as Asturias is not the only place in which it can be observed. There are other regions worldwide, such as the Spanish autonomous communities of Murcia or the Canary Islands, the Seychelles islands, or the municipality of Puerto Gaitán in Colombia (Ramírez, 2012) where these naturalistic narratives linked to a 'natural paradise' have been employed to some extent.

As a result, rural landscapes in Asturias are reified as products in an attempt to build attractive experiences for tourism consumption, while the perceptions and efforts made by the local communities are silenced; landscapes become asocial and atemporal. Thus, rural farming families are not being represented in this 'natural paradise'; to the contrary, they are being excluded from these commodified images, despite the fact that they and their ancestors shaped those landscapes through their productive activities and their resilient way of life. This way, the inhabitants of the rural areas become subaltern actors with almost no say in the matter (Spivak, 1988), as they are marginalised from the contemporary policy-making processes regarding the management of their surrounding landscapes, which are primarily developed by technical circles in the cities.

At some point, the rural farming communities realised that they had been left out of the picture, and some of them reacted against the governmental 'Paradise keepers'. An unofficial Facebook fan page called 'Asturian keepers' (from Asturian Guardianes d'Asturies) ${ }^{5}$ can be considered a good example of these reactions to the above mentioned promotions. Alternative views on the official campaign were shared, along with news and statements about the decline of the Asturian countryside. Old potos showing traditional livelihoods and links to ethnographic studies were shared on the same space, with a significant impact. Furthermore, a sort of 'bottom-up' campaign with graphic compositions about the real paradise keepers was launched. Thus, farmers, herders and craftsmen were distinguished as those 'Asturian keepers' [Figure 5]. This fan page reached almost 2000 followers as its scope broadened to include Facebook users from rural areas of Asturias after the official 'Paradise keepers' campaign was launched in 2014. Interestingly, some of the comments in the Facebook fan page reveal a feeling of abandonment by public institutions that are more concerned - in the opinion of the rural inhabitants of Asturias - on attracting more tourists towards the 'natural paradise'. This 'bottom-up' campaign resulted in the strengthening and the dissemination of alternative narratives and shows an emerging conflicto between different stakeholders in this region each according to their own agenda.

This controversial situation threatens the success of future initiatives for the sustainable development of rural Asturias, since the local inhabitants of these areas mistrust the use of 'naturalistic' discourses about the environment. So, the mutual failure of governmental experts and rural communities to understand the other's position would become an insurmountable obstacle for establishing a mutual empathy. As motives for this dispute, we could highlight the defensive attitude deployed by local farming families regarding these technical 'naturalistic' narratives, the lack of empathy with the other shown by governmental technicians and experts, and the absence of social scientists in this context for addressing the cultural and political aspects of the dispute.

Taking this into consideration, archaeologists should get involved in this conflict and strengthen rural farming communities' agency. Our active involvement would be useful for local communities in order to humanise current views on landscapes and to demonstrate the historical depth from which landscapes have been constructed by societies throughout history. 
Archaeological research can really make a difference in emphasising the diachronic nature and the social roots of the cultural landscapes, as applied to public debate. It can also play a pivotal role in establishing a holistic vision on public narratives about landscapes including the role deployed by local communities through history. This consideration should be seriously taken into account when designing tourism, territory and Heritage management policies. If archaeologists and other social scientists do not take into account these considerations and bring them to light, simplistic discourses constructed from a tourism marketing point of view will predominate.

\section{The social construction of cultural landscapes in the longue durée}

Landscapes around us are palimpsests in which traces left by successive generations or communities who inhabited a territory melt together. However, this essential characteristic is entirely ignored by the atemporal tourism narratives linked to the 'natural paradise' premise in Asturias. Landscape Archaeology research has shown the relevance of human activities in the formation of European landscapes (Anschuetz, Wilshusen, \& Scheick, 2001; Aston, 1985; Criado, 1999; David \& Thomas, 2008), even in the most remote areas such as the highest mountains (Gassiot et al., 2014; Walsh, 2008). This point of view helps us generate an open discussion regarding the political, social and economic 'historicity' of landscape formation processes at all times. In fact, such aspects were present in the daily lives of the people who transformed their environment and gave meaning to those cultural landscapes through their own identity and their experiences (Ingold, 2000; Tilley, 1994). Without delving into all the different historical periods, we can delimitate a selection of cultural and social processes that occurred in the last millennia and stand out as precedents for some of the features that nowadays characterise the diversity of Asturian cultural landscapes (Fernández-Salinas, 2013). Thus, we can emphasise the relevance of social action in shaping the current image of our landscapes.

The persistent anthropisation of the landscape began around 6000 years ago, when the neolithic communities started to shape the Western Cantabrian area as a result of activities such as agriculture and pastoralism (Cubas-Morera et al., 2016). It was thus that the sweat and effort employed by those Pioneer farmers and herders from the Neolithic began to shape the Asturian landscapes into their current form. These groups had itinerant livelihoods in relation to extensive agricultural and pastoralist strategies (González-Álvarez, 2016). As a result of their actions, forests were cleared into open areas for crops and pastures. Monte Areo peat bog, nearby the city of Gijón, shows the earliest evidence of cereal pollen in the region by ca. 4800 cal BC (López-Merino, Martínez-Cortizas, \& López-Sáez, 2010). This deposit is located near the coastline, in a low hill area where plenty of megalithic burial mounds can be found (de Blas, 1999). We can consider these structures as anthropogenic modifications of the landscape itself, besides monumentalised manifestations of the symbolic domestication of interesting productive áreas (González-Álvarez, in press). Actually, some of them are dated a few centuries later than the apparition of the first cereal signs in the paleoenvironmental sequence of Monte Areo, so they could be linked to the consolidation of the Neolithic landscapes (Arias-Cabal et al., 2000). By contrast, deforestation related to herding activities or cereal crops seems to be a later phenomenon in mountainous areas in comparison to coastal areas or inland valleys, as can be detected ca. $4000 \mathrm{cal}$ BC in other paleoenvironmental deposits such as La Molina peat bog, at $650 \mathrm{~m}$ high (López-Merino, Martínez-Cortizas, \& López-Sáez, 2011), or Enol Lake at $1070 \mathrm{~m}$ high (Moreno et al., 2011). Furthermore, there are some pollen records in natural deposits, such as El Valle Lake at $1570 \mathrm{~m}$ high, where anthropogenic activities on the vegetation cover can barely be noted until the end of Late Prehistory (Allen, Huntley, \& Watts, 1996).

During the Bronze age, the anthropogenic influence in the environment increased substantially, as a consequence of a more extensive pressure applied by the human groups through agriculture, pastoralist and mining activities. However, although the archaeological data is scarce, it appears that the livelihoods of the communities who inhabited Asturias in this period 
did not change too much in comparison to previous neolithic groups (Arias-Cabal \& Armendáriz, 1998; Marín, 2009). Thereby, the pressure on forest areas in relation to the extension of agriculture and pastoralism increased across the region, with a clear impact also in the uplands (López-Sáez, López-García, \& López-Merino, 2006) and diversification in lower agrarian landscapes (López-Merino et al., 2011). Moreover, mining activities started at the end of the third millennium cal BC for the extraction of copper in several parts of the Cantabrian Mountains (de Blas \& Suárez, 2010), which establishes a distant precedent for the significant impact that mining activities have exerted on contemporary Asturian culture and identity. The development of metallurgy caused an increase in atmospheric metal pollution which can be tracked back to certain peat bog sequences (Martínez-Cortizas, López-Merino, Bindler, Mighall, \& Kylander, 2016). The growing interaction of human groups with their surroundings in the Bronze Age also left its impression on the social and cultural landscapes, which became more territorialised. Thus, archaeological manifestations such as schematic rock art linked to 'natural monuments' and special points in the natural routes through the mountains (de Blas, 2003), the maintenance of Megalithism in the uplands (Marín, 2009), the appearance of metallic hoards related to liminal spaces and nodal points in the landscapes (Ruiz-Gálvez, 1998), along with the increasing anthropogenic impact on the environment, show more permanent relationships between the groups and their territories, although they were still itinerant.

Around 2800 years ago, the earliest sedentary communities in this territory configured a new settlement pattern in the Iron Age based on hillforts (González-Ruibal, 2008; Marín, 2011; Parcero, 2002) [Figure 6]. During the first millennium BC, a new livestock management system focused on cattle was developed, with vertical transhumance emerging as the main pastoralism model in this mountainous region. This system is similar to that of preindustrial peasant communities in the región until the twentieth century (González-Álvarez, Fernández-Mier, \& López Gómez, 2016) [Figure 7]. Meanwhile, agriculture was intensified with new iron tools, the diversification of cultivated species and the appearance of the first stable crop fields near the hillforts. While data are scarce for Asturian Later Prehistory, traces of these type of fields underlay the sub-actual fields and meadows, as Rescue Archaeology investigations have recently managed to show in nearby regions such as Galicia (Parcero, 2006). Thus, a compartmentalised landscape emerged in which the anthropisation processes worked in a nuclearised manner around the monumentalised hillforts (González-Álvarez, 2016), much as it occurs in Asturian hamlets in present times.

This settlement pattern endured until the Roman conquest of the territory 2000 years ago, when the Western Cantabrian Mountains were integrated into the Roman Empire. After a rapid political and selfperception change in the local communities, most of the hillforts were abandoned (Marín \& González-Álvarez, 2011) and a network of peasant open-settlements emerged, constituting the initial germ of the small villages in the Asturian rural landscape (Fernández-Mier, 2009), along with the Roman villae where local elites lived (Fernández-Ochoa \& Gil-Sendino, 2008) [Figure 8(a)]. Gold mining had a great impact on several areas (Domergue, 1990), modifying the valley shape, increasing deforestation (López-Merino et al., 2014) and introducing the foundations of a more hierarchical, socio-political landscape (Sastre, 2001).

After Late Antiquity, peasant settlements were territorially organised with the consolidation of a medieval rural parish network in connection with the emergence of feudalism (FernándezConde, Gutiérrez-González, Suárez-Álvarez, Arias-Páramo, \& Fernández-Mier, 2009; García Álvarez-Busto \& Muñiz-López, 2010). Subsequently, this territorialisation process would be strengthened since the Late Medieval period with the founding of small towns inhabited by the nobility and the bourgeoisie (Ruiz de la Peña, 1981), most of which constitute the head of the local municipalities in the Asturian countryside nowadays [Figure 8(b)].

During the modern period, American crops such as corn or potatoes were introduced in Asturias causing a substantial transformation of the agricultural system and the ordination of field systems (García-Fernández, 1988) (Figure 9). These new products - which were grown in new 
terraced agrarian areas (Fernández-Mier, 2010) - would become the fundamental ingredients of the Asturian gastronomy, such as the fabada (an Asturian traditional bean and pork meat stew). In this period, tensions arose between local communities, the nobility, the church and the state in their aim to control the common lands (Corbera, 2003; Fernández-Mier, López Gómez, \& González-Álvarez, 2013), with the confiscation of municipal and ecclesiastic goods in the nineteenth century affecting again the composition of the agrarian landscape (García-Pérez, 1993; Moro, 1981).

Since the late nineteenth century - and especially throughout the twentieth century industrialisation had a significant impact on Asturias. Coal mining and heavy industry transformed the landscape and generated rapid growth in the cities. Heavy demand for labour force by the new industries as well as the overall modernisation of Spain significantly increased the rural exodus of the Asturian countryside, which was supported by the state during the Franco dictatorship (Aceves, 1978). However, as a consequence of globalisation and the entrance of Spain in the European Union, the preindustrial traditional culture in Asturias declined (García-Martínez, 2011; Rodríguez \& Menéndez, 2005).

Attending to the genealogy of Asturian cultural landscapes, they should be considered as

both a work (it is the product of human labour and thus encapsulates the dreams, desires and all the injustices of the social systems that make it), and as something that does work (it acts as a social agent in the further development of a place). (Mitchell, 1998, p. 94)

Undoubtedly, all these episodes brought changes and novelties; some of these features endured throughout history and have become fundamental footprints in the present Asturian countryside, while others represented momentary traits without continuity. For this reason, the archaeological reading of landscapes can emphasise diachrony laying in the basis of current rural landscapes in Asturias.

\section{Tourism marketing versus local communities}

The Asturian landscape has been shaped by people since the Neolithic. Farmers and herders taking advantage of the soil potential determined the anthropogenic construction of the rural landscapes [Figure 10]. By taking into consideration the temporal depth and the strong cultural component of these landscapes, we could critically reflect on the discursive background from the official tourism narratives in Asturias. Thus, the campaign 'Asturias, Natural Paradise' ignores the anthropogenic element of the landscape - which becomes atemporal - and renders invisible the experiences and the people who contributed to that landscape. In terms of marketing the success of these campaigns cannot be disputed, as they are undoubtedly meeting their target. But we cannot simply assume that tourism imaginaries ought to be designed merely to stimulate consumption, since the spread of images and the narratives attached to them have an impact on the local communities (Salazar, 2012, p. 876).

The tourism imaginaries built around the slogan 'Asturias, Natural Paradise' have created an outstanding referent for contemporary Asturian identity; still, a portion of its population - the farming families and their descendants - does not recognise itself in those narratives. At the same time, these citizens are excluded from the deliberation and decision-making processes which govern their own territories. The spread of more and more complex regulations designed mainly by technicians, the proliferation of bureaucracy and the extension of the neoliberal formulae of governance (Alonso-González \& Macías-Vázquez, 2014) have cornered the local communities, who are barely able to actively participate in the management of their own villages and the surrounding landscapes. Meanwhile, the crisis in the countryside - emerging as a result of globalisation - and the end of protectionism on the primary sector have accelerated the depopulation of rural Asturias (Camarero et al., 2009). Remaining in the rural villages and living off the land seems an impossible, yet crucial task nowadays, becoming a dead-end or a solitary effort undertaken by the latest generation of farmers and herders (García-Martínez, 
2011). The dismantling of this way of life will result in a loss of cultural heritage, environmental diversity and landscape values. Meanwhile, rural tourism emerges as an economic activity and a niche job. Perhaps we are witnessing an identity break point in Asturians' future. Have campaigns such as 'Asturias, Natural Paradise' contributed to stanch the wound? Or have they helped to bleed the pride of Asturian rural identity to death? Do we, as archaeologists, have anything to say?

\section{A call for action}

By opening this debate, it has been my intention to address the sociological and political consequences that the consolidation of 'Asturias, Natural Paradise' tourism imaginaries pose for the inhabitants of the Asturian rural areas. 'Tourism imaginaries renegotiate political and social realities' (Salazar, 2012, p. 877), as it can be perceived in the contemporary construction of an Asturian identity subordinated to a naturalistic and atemporal view on cultural landscapes. In this sense, official tourism discourses are mainly based on presentist narratives which tend to undervalue and silence the active role that local communities have played in shaping the Asturian landscapes. On the whole, the relevance of farming families to the shaping of the cultural landscapes of rural Europe needs to be further highlighted.

The disconnection between Archaeology and the design of these governance formulae in technical contexts facilitates an absence of awareness of the temporal depth that characterises cultural landscapes in international regulations such as UNESCO conventions or the European Landscape Convention (Jacques, 1995; Rössler, 2006). These concepts are therefore used in a broad sense, as empty signifiers derived from regulations which systematically ignore academic discussion about the aforementioned concepts (Sabaté-Bel, 2011, p. 12). For the most part, social scientists have confronted this issue with silence. While lengthy descriptions of the situations described in this paper have occasionally been produced, scholars have seldom taken an active role in the social and political debate. However, as archaeologists, we possess sufficient capacity for action to aid local communities in significant ways. In my opinion, this is the goal that archaeologists, as social scientists, should strive for, following the ideas stated by Antonio Gramsci (1998).

With this in mind, the diachronic narratives on cultural landscapes produced by archaeologists - amongst other social scientists - can generate multivocality, making it possible for subaltern rural farming communities to voice their opinion. Certainly, Landscape Archaeology research emphasises the relevant role of farmers as the historical agents who did work the land, thus enabling the long-term changes that shaped the landscapes into their current form. At the same time, we can stress the importance of Archaeology in order to inform about the social, political and economic traits which catalyse these diachronic processes. This reflection contrasts enormously with the naturalistic and atemporal speeches that are being established thanks to slogans and tourism promotions such as 'Asturias, Natural Paradise'.

A first step forward could be the dissemination of alternative discourses (Alberti \& Marshall, 2009) which may reinforce the local farming communities' positions as stakeholders for the future design of rural policies. To this end, Landscape Archaeology can provide comprehensive narratives about cultural landscapes which question the atemporal discourses derived from tourism imaginaries such as 'Asturias, Natural Paradise'. Furthermore, these diachronic interpretations of cultural landscapes can strengthen the role of Archaeology as a valuable social science for rethinking the future of rural Europe.

In this sense, community Archaeology reflections focused on the relevance of heritage and landscapes to the local communities' memory could be taken as an example (e.g. Tully \& Hanna, 2013; Waterton, 2005). From this perspective, the cultural aspects of the genealogy of rural landscapes would be an invaluable asset in order to promote the self-awareness of local communities and enhance their role in shaping the cultural landscapes of the European 
countryside. There are already a few examples in Asturias which encourage this path of action (e.g. Fernández-Fernández, 2013), and the results on those rural communities invite optimism.

The rural farming communities barely have access to the scenarios where public policies are shaped, their voices seldom being taken into account. Following the experiences that can be observed in cultural parks around the world (Alonso-González, 2013), it can be argued that these communities gain Access to the technical and political decision-making places in which the governance formulae on tourism and Heritage management are designed.

As we have established in this paper, archaeological narratives on the anthropisation processes and the social construction of cultural landscapes throughout history emphasise the outstanding role of farming families in the making of Asturian landscapes. Armed with this knowledge, archaeologists can argue in favour of the direct participation of these key stakeholders in the design of future Heritage and territorial policies.

Moreover, we archaeologists - along with other social scientists - should endeavour to be present in the design of said policies. Having taken into consideration the importance of farmers' agency as landscape-makers, we could play an active role in mediating between rural communities and governmental actors and assisting in the development of positive selfawareness among the inhabitants of rural Asturias, with the ultimate aim of ensuring that the local voices that shaped these landscapes are never silenced in the decision-making processes.

\section{Notes}

1. Website of the official tourism agency: http://www.turismoasturias.es/

2. http://whc.unesco.org/archive/repcom85.htm\#312

3. http://www.Ine.es/asturias/2015/06/06/principado-celebr-30-aniversario-marca/1 768 518.html

4. http://www.dominicasoviedo.com/publicaciones/actividades-y-celebraciones/item/1484-eso-3-y-4dibujosconcurso-central-lechera

5. http://www.facebook.com/Guardianes-d-Asturies-136853896486999/

\section{Funding}

This work was supported by the Axencia Galega de Innovación, Consellería de Economía, Emprego e Industria from the Galician regional government (Spain) through the Postdoctoral Support Program [grant number IN606B-2016/007].

\section{References}

Aceves, J. B. (1978). Olvidados por Madrid: Notas sobre la planificación del desarrollo rural en España. In J. B. Aceves \& W. A. Douglass (Eds.), Los aspectos cambiantes de la España rural (pp. 229-238). Barcelona: Barral.

Alameda, D, \& Fernández, E. (2012). La comunicación de las marcas territorio. In C. Mateos, C. E. Hernández, F. J. Herrero, S. Toledano, \& A. I. Ardèvol (Eds.), Actas IV Congreso Internacional Latina de Comunicación Social: Comunicación, control y resistencias. La Laguna: Sociedad Latina de Comunicación Social. Retrieved from http://www.revistalatinacs.org/12SLCS/2012 actas/160 Alameda.pdf

Alberti, B., \& Marshall, Y. (2009). Animating archaeology: Local theories and conceptually open-ended methodologies. Cambridge Archaeological Journal, 19(3), 344-356.

Allen, J. R. M., Huntley, B., \& Watts, W. A. (1996). The vegetation and climate of northwest lberia over the last 14,000 years. Journal of Quaternary Science, 11(2), 125-147.

Alonso-González, P. (2013). Cultural parks and national heritage areas: Assembling cultural heritage, development and spatial planning. Newcastle-upon-Tyne: Cambridge Scholars Publishing. 
Alonso-González, P., \& Macías-Vázquez, A. (2014). Neoliberalismo corporativo y clientelismo en España: Etnografía de la financiación europea del desarrollo rural a través de un proyecto fallido. AIBR. Revista de Antropología Iberoamericana, 9(3), 223-250.

Anschuetz, K. F., Wilshusen, R. H., \& Scheick, C. L. (2001). An archaeology of landscapes: Perspectives and directions. Journal of Archaeological Research, 9(2), 157-211.

Arias-Cabal, P., \& Armendáriz, A. (1998). Aproximación a la Edad del Bronce en la Región Cantábrica. In R. Fábregas (Ed.), A Idade do Bronce en Galicia: Novas Perspectivas (pp. 47-80). A Coruña: Ediciós do Castro.

Arias-Cabal, P., Altuna, J., Armendáriz, A., González-Urquijo, J. E., Ibáñez, J. J., Ontañón, R., \& Zapata-Peña, L. (2000). La transición al Neolítico en la Región Cantábrica. Estado de la Cuestión. In P. Arias-Cabal, P. Bueno-Ramírez, D. Cruz, J. X. Enríquez, J. Oliveira \& M. J. Sanches (Eds.), Actas do 3o Congresso de Arqueologia Peninsular, vol.3: Neolitizaçao e Megalitismo da Peninsula Ibérica (pp. 115-131). Porto: ADECAP.

Aston, M. (1985). Interpreting the landscape. London: Routledge.

Camarero, L., Cruz, F., González, M., del Pino, J. A., Oliva, J., \& Sampedro, R. (Eds.). (2009). La población rural de España. De los desequilibrios a la sostenibilidad social. Barcelona: Obra Social Fundación La Caixa.

Comaroff, J. L., \& Comaroff, J. (2009). Ethnicity, inc. Chicago, IL: The University of Chicago Press.

Corbera, M. (2003). Campesinos y montes en Cantabria: Competencia y conflictos por los aprovechamientos entre los siglos XVII y XIX (1650-1850). In C. Vázquez \& J. S. García (Eds.), Las relaciones entre las comunidades agrícolas y el monte: Coloquio hispano-francés de geografía rural (pp. 183-196). Cuenca: Universidad de Castilla-La Mancha.

Criado, F. (1999). Del terreno al espacio: Planteamientos y perspectivas para la Arqueología del Paisaje. Santiago de Compostela: Universidade de Santiago de Compostela.

Cubas-Morera, M., Altuna, J., Álvarez-Fernández, E., Armendáriz, A., Fano, M. A., López-Dóriga, I. L., ... Arias-Cabal, P. (2016). Re-evaluating the Neolithic: The Impact and the consolidation of farming practices in the Cantabrian region (Northern Spain). Journal of World Prehistory, 29(1), 79-116.

David, B., \& Thomas, J. (Eds.). (2008). Handbook of landscape archaeology. Walnut Creek, CA: Left Coast Press.

de Blas, M. A. (1999). El Monte Areo, en Carreño (Asturias): Un territorio funerario de los milenios $V$ a III a.C. Candás: Ayuntamiento de Carreño.

de Blas, M. A. (2003). Estelas con armas: Arte rupestre y paleometalurgia en el norte de la Península Ibérica. In R. Balbín \& P. Bueno (Eds.), El arte prehistórico desde los inicios del siglo XXI. Primer Symposium Internacional de Arte Prehistórico de Ribadesella (pp. 391-417). Ribadesella: Amigos de Ribadesella.

de Blas, M. A., \& Suárez, M. (2010). La minería subterránea del cobre en Asturias: Un capítulo esencial en la Prehistoria reciente del norte de España. In J. Fernández-Tresguerres (Ed.), Cobre y Oro. Minería y metalurgia en la Asturias prehistórica y antigua (pp. 43-82). Oviedo: RIDEA.

Domergue, C. (1990). Les mines de la Péninsule Ibérique dans l'Antiquité romaine. Roma: École Française de Rome.

Fernández-Conde, F. J., Gutiérrez-González, J. A., Suárez-Álvarez, M. J., Arias-Páramo, L., \& FernándezMier, M. (2009). Poderes sociales y políticos en Asturias. Siglos VIII-IX. Territorio, Sociedad y Poder, Anejo, 2, 11-30.

Fernández-Fernández, J. (2013). La Ponte, un proyecto de ecomuseo para Santo Adriano (Asturias): Hacia un modelo de gestión comunitaria del patrimonio cultural. Cuadiernu: Difusión, investigación y conservación del patrimonio cultural, 1, 7-22.

Fernández-Mier, M. (2009). La génesis de la aldea en las provincias de Asturias y León. In J. A. QuirósCastillo (Ed.), The Archaeology of Early Medieval Villages in Europe (pp. 149-165). Bilbao: Universidad del País Vasco.

Fernández-Mier, M. (2010). Campos de cultivo en la Cordillera Cantábrica. La Agricultura en zonas de montaña. In H. Kirchner (Ed.), Por una arqueología agraria. Perspectivas de investigación sobre espacios de cultivo en las sociedades medievales hispánicas (pp. 41-59). Oxford: Archaeopress.

Fernández-Mier, M., López Gómez, P., \& González-Álvarez, D. (2013). Prácticas ganaderas en la Cordillera Cantábrica. Aproximación multidisciplinar al estudio de las áreas de pasto en la Edad Media. Debates de Arqueología Medieval, 3, 167-219. 
Fernández-Ochoa, C., \& Gil-Sendino, F. (2008). La villa romana de Veranes (Gijón, Asturias) y otras villas de la vertiente septentrional de la Cordillera Cantábrica. In C. Fernández-Ochoa, V. García-Entero, \& F. Gil-Sendino (Eds.), Las villae tardorromanas en el occidente del Imperio. Arquitectura y función (pp. 435-480). Gijón: Trea.

Fernández-Salinas, V. (2013). Los paisajes de interés cultural de Asturias. Ería, 91, 129-149.

García Álvarez-Busto, A., \& Muñiz-López, I. (2010). Arqueología medieval en Asturias. Gijón: Trea.

García-Fernández, J. (1988). Sociedad y organización tradicional del espacio en Asturias. Gijón: Silverio Cañada.

García-Martínez, A. (2011). Antropología de Asturias II. El cambio: La imagen invertida del otro. Oviedo: KRK.

García-Pérez, J. (1993). Efectos de la desamortización sobre la propiedad y los cultivos. Ayer, 9, 105-173.

Gassiot, E., Rodríguez-Antón, D., Pèlachs, A., Pérez-Obiol, R., Julià, R., Bal-Serin, M. C., \& Mazzucco, N. (2014). La alta montaña durante la Prehistoria: 10 Años de investigación en el Pirineo catalán occidental. Trabajos de Prehistoria, 71(2), 261-281.

González-Álvarez, D. (2016). Poblamiento y antropización de la montaña occidental cantábrica durante la Prehistoria reciente: Una aproximación desde la Arqueología del Paisaje (PhD dissertation). Universidad Complutense de Madrid, Madrid.

González-Álvarez, D. (in press). La antropización de los espacios montañosos del Occidente Cantábrico: EI Neolítico en el valle del río Pigüeña (Asturias). In Actas del VI Congreso del Neolítico en la Península Ibérica. Granada: Universidad de Granada.

González-Álvarez, D., Fernández-Mier, M., \& López Gómez, P. (2016). An archaeological approach to the brañas: Summer farms in the pastures of the Cantabrian mountains (northern Spain). In J. R. Collis, M. Pearce, \& F. Nicolis (Eds.), Summer farms. Seasonal exploitation of the uplands from prehistory to the present (pp. 203-219). Sheffield: Equinox.

González-Ruibal, A. (2008). Los pueblos del noroeste. In F. Gracia (Ed.), De Iberia a Hispania (pp. 899-930). Madrid: Ariel.

Gramsci, A. (1998). Para la reforma moral e intelectual. Madrid: Los Libros de la Catarata.

Hellín, P. A. (2007). Publicidad verde. La ecología y el respeto al medio ambiente como estrategias persuasivas en la publicidad turística. In F. R. Contreras, A. Caraballo, M. Gómez, \& I. Daza (Eds.), Cultura verde: Ecología, cultura y comunicación (pp. 209-228). Sevilla: Junta de Andalucía.

Hirsch, E., \& O'Hanlon, M. (Eds.). (1995). The anthropology of landscape. Perspectives on place and space. Oxford: Clarendon Press.

Ingold, T. (2000). The perception of the environment. London: Routledge.

Jacques, D. (1995). The rise of cultural landscapes. International Journal of Heritage Studies, 1(2), 91-101. Johnson, M. H. (2007). Ideas of landscape. Oxford: Blackwell Publishing.

López-Merino, L., Martínez-Cortizas, A., \& López-Sáez, J. A. (2010). Early agriculture and palaeoenvironmental history in the North of the Iberian Peninsula: A multi-proxy analysis of the Monte Areo mire (Asturias, Spain). Journal of Archaeological Science, 37(8), 1978-1988.

López-Merino, L., Martínez-Cortizas, A., \& López-Sáez, J. A. (2011). Human-induced changes on wetlands: A study case from NW Iberia. Quaternary Science Reviews, 30(19-20), 2745-2754.

López-Merino, L., Martínez-Cortizas, A., Reher, G. S., López-Sáez, J. A., Mighall, T. M., \& Bindler, R. (2014). Reconstructing the impact of human activities in a NW Iberian Roman mining landscape for the last 2500 years. Journal of Archaeological Science, 50, 208-218.

López-Sáez, J. A., López-García, P., \& López-Merino, L. (2006). El impacto humano en la Cordillera Cantábrica: Estudios palinológicos durante el Holoceno Medio. In J. M. Maíllo \& E. Baquedano (Eds.), Miscelánea en homenaje a Victoria Cabrera (pp. 123-130). Alcalá: Museo Arqueológico Regional de Madrid.

Marín, C. (2009). De nómadas a castreños. Los orígenes de la Edad del Hierro en Asturias. In C. Marín \& J. F. Jordá-Pardo (Eds.), Arqueología castreña en Asturias (pp. 21-46). Gijón: UNED.

Marín, C. (2011). De nómadas a castreños. Arqueología del primer milenio antes de la era en el sector centro-occidental cantábrico (PhD dissertation). Universidad Complutense de Madrid, Madrid.

Marín, C., \& González-Álvarez, D. (2011). La romanización del Occidente Cantábrico: De la violencia física a la violencia simbólica. Férvedes, 7, 197-206. 
Martínez-Cortizas, A., López-Merino, L., Bindler, R., Mighall, T., \& Kylander, M. (2016). Early atmospheric metal pollution provides evidence for Chalcolithic/Bronze age mining and metallurgy in Southwestern Europe. Science of The Total Environment, 545-546, 398-406.

Martínez-Expósito, A. (2014). La marca Asturias en el cine español: De Volver a empezar a Vicky Cristina Barcelona. In S. Bando \& M. Insúa (Eds.), Actas del II Congreso ibero-asiático de hispanistas (Kioto, 2013) (pp. 341-355). Pamplona: Universidad de Navarra.

Mitchell, D. (1998). Cultural geography: A critical introduction. Oxford: Basil-Blackwell.

Moreno, A., López-Merino, L., Leira, M., Marco-Barba, J., González-Sampériz, P., Valero-Garcés, B. L., ... Ito, E. (2011). Revealing the last 13,500 years of environmental history from the multiproxy record of a mountain lake (Lago Enol, northern Iberian Peninsula). Journal of Paleolimnology, 46(3), 327349.

Moro, J. M. (1981). La desamortización en Asturias en el siglo XIX. Gijón: Silverio Cañada.

Parcero, C. (2002). La construcción del paisaje social en la Edad del Hierro del Noroeste ibérico. Ortigueira: Fundación Ortegalia.

Parcero, C. (2006). Los paisajes agrarios castreños. Modelos de construcción del espacio agrario a lo largo de la Edad del Hierro del noroeste. Arqueología Espacial, 26, 57-85.

Plumed, M. (2014). Estudio del desarrollo del place branding a partir del análisis de las marcas territoriales existentes en España. Papers de Turisme, 56, 119-143.

Ramírez, S. (2012). Imaginando «El paraíso natural»: representación y modernidad en Puerto Gaitán, Meta. Tabula Rasa, 17, 153-170.

Ritzer, G., \& Liska, A. (1997). 'McDisneyization' and 'Post-tourism'. In C. Rojek \& J. Urry (Eds.), Touring cultures. Transformations of travel and theory (pp. 96-109). London: Routledge.

Rodríguez, F., \& Menéndez, R. (2005). Geografía de Asturias: La reestructuración territorial de una región de tradición industrial. Barcelona: Ariel.

Rössler, M. (2006). World heritage cultural landscapes: A UNESCO flagship programme 1992-2006. Landscape Research, 31(4), 333-353.

Ruiz de la Peña, J. I. (1981). Las «Polas» asturianas en la Edad Media. Estudio y diplomatario. Oviedo: Universidad de Oviedo.

Ruiz-Gálvez, M. (1998). La Europa Atlántica en la Edad del Bronce. Barcelona: Crítica.

Sabaté-Bel, J. (2011). De la Preservación del Patrimonio a la Ordenación del Paisaje: Intervenciones en Paisajes Culturales de Latinoamérica. In Paisajes Culturales: Comprensión, Protección y Gestión (pp. 10-23). Madrid: AECID.

Salazar, N. B. (2010). Envisioning eden. Mobilizing imaginaries in tourism and beyond. Brooklyn, NY: Berghahn Books.

Salazar, N. B. (2012). Tourism imaginaries: A conceptual approach. Annals of Tourism Research, 39(2), $863-882$.

Sastre, I. (2001). Las formaciones sociales rurales de la Asturia romana. Madrid: Ediciones Clásicas.

Sauer, C. O. (1925). The morphology of landscape. University of California Publications in Geography, 2(2), 19-53.

Spivak, G. (1988). Can the subaltern speak? In C. Nelson \& L. Grossberg (Eds.), Marxism and the interpretation of culture (pp. 271-313). Urbana: University of Illinois Press.

Tilley, C. (1994). A phenomenology of landscape. Places, paths and monuments. Oxford: Berg.

Tully, G., \& Hanna, M. (2013). One landscape, many tenants: Uncovering multiple claims, visions and meanings on the Theban necropolis. Archaeologies, 9(3), 362-397.

Valdés, L., Aza, R., \& Baños, J. (2010). Impacto económico del turismo en una región: El caso de Asturias. Cuadernos de Economía, 33(91), 183-208.

Walsh, K. (2008). Mediterranean landscape archaeology: Marginality and the culture-nature 'Divide'. Landscape Research, 33(5), 547-564.

Wang, N. (1999). Rethinking authenticity in tourism experience. Annals of Tourism Research, 26(2), 349370.

Waterton, E. (2005). Whose sense of place? Reconciling archaeological perspectives with community values: Cultural landscapes in England. International Journal of Heritage Studies, 11(4), 309-325. 


\section{Figures}

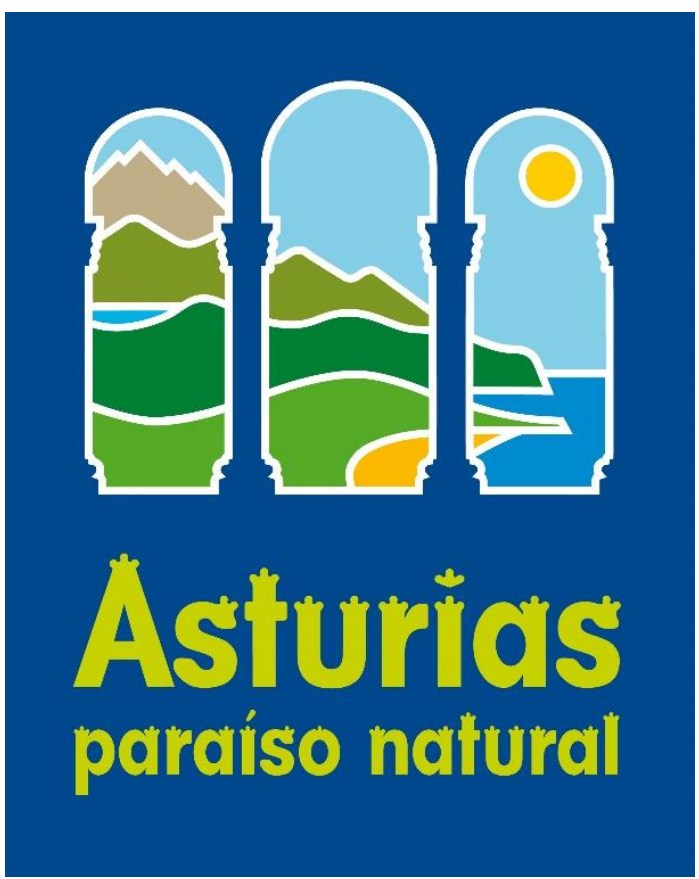

Figure 1. 'Asturias, Natural Paradise' campaign logo.
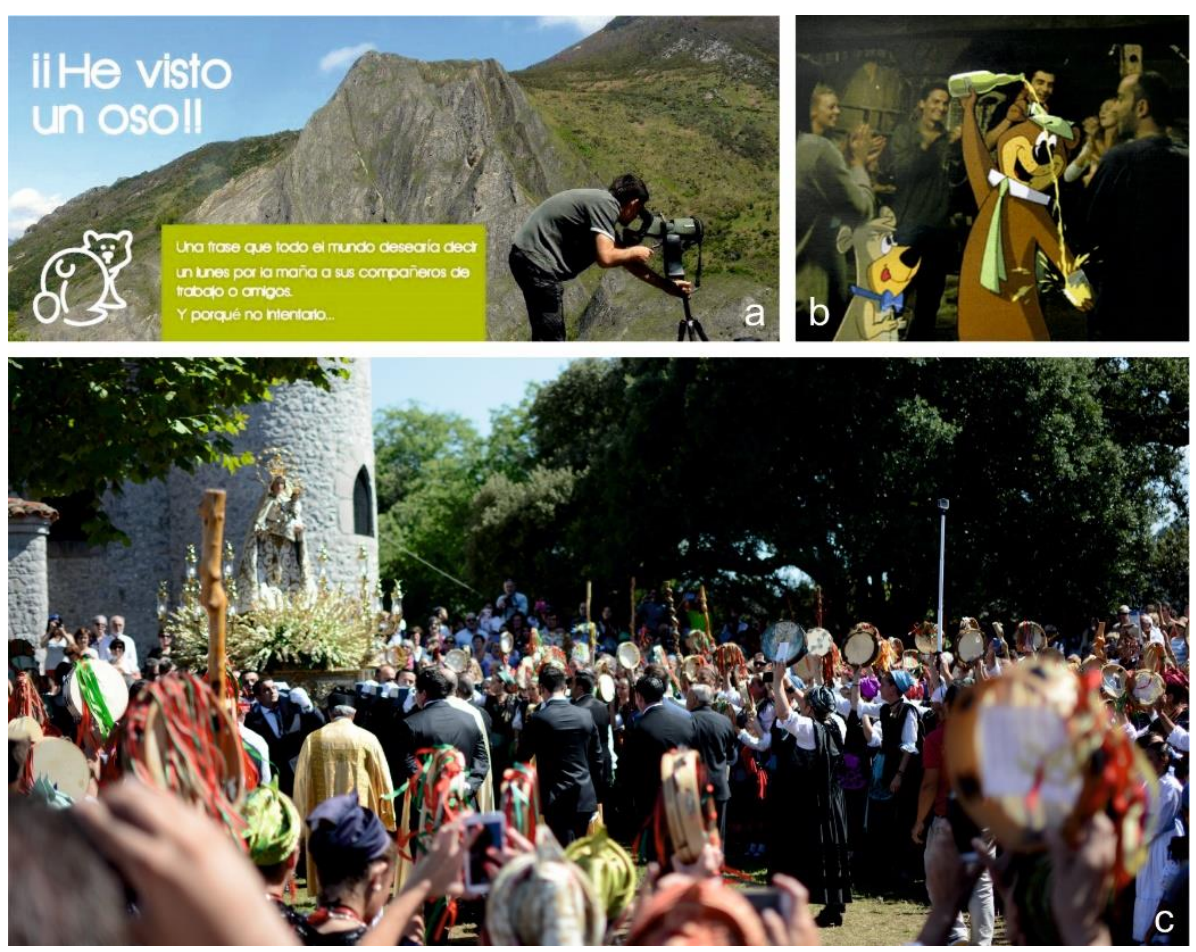

Figure 2. (a) Fuentes del Narcea natural park's official poster which reads 'I've seen a bear!! A sentence that everyone would like to say next Monday in their office to their workmates and friends ... Why don't you try it?'; (b) the Hanna Barbera Yogi and Boo-Boo characters pour cider in a traditional Asturian cider house on an official advertisement for the 'Asturias, Natural Paradise' campaign; (c) traditional celebrations of the 2016 Fiesta del bandu La Guía in Llanes (Asturias) in which the participants wear traditional clothes, perform vernacular dances and play music in front of hundreds of tourists (source: Llorián García Flórez). 


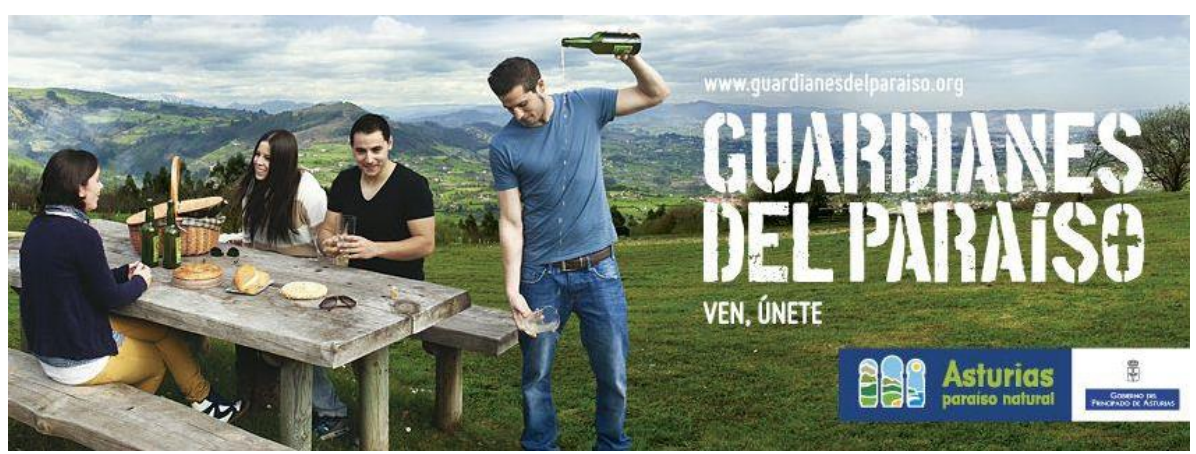

Figure 3. Complementing the 'Asturias, Natural Paradise' promotions, the 'Paradise keepers' campaign produced advertisements like the one that is reproduced in this image in which a group of tourists have lunch and pour cider in an idyllic Asturian landscape.
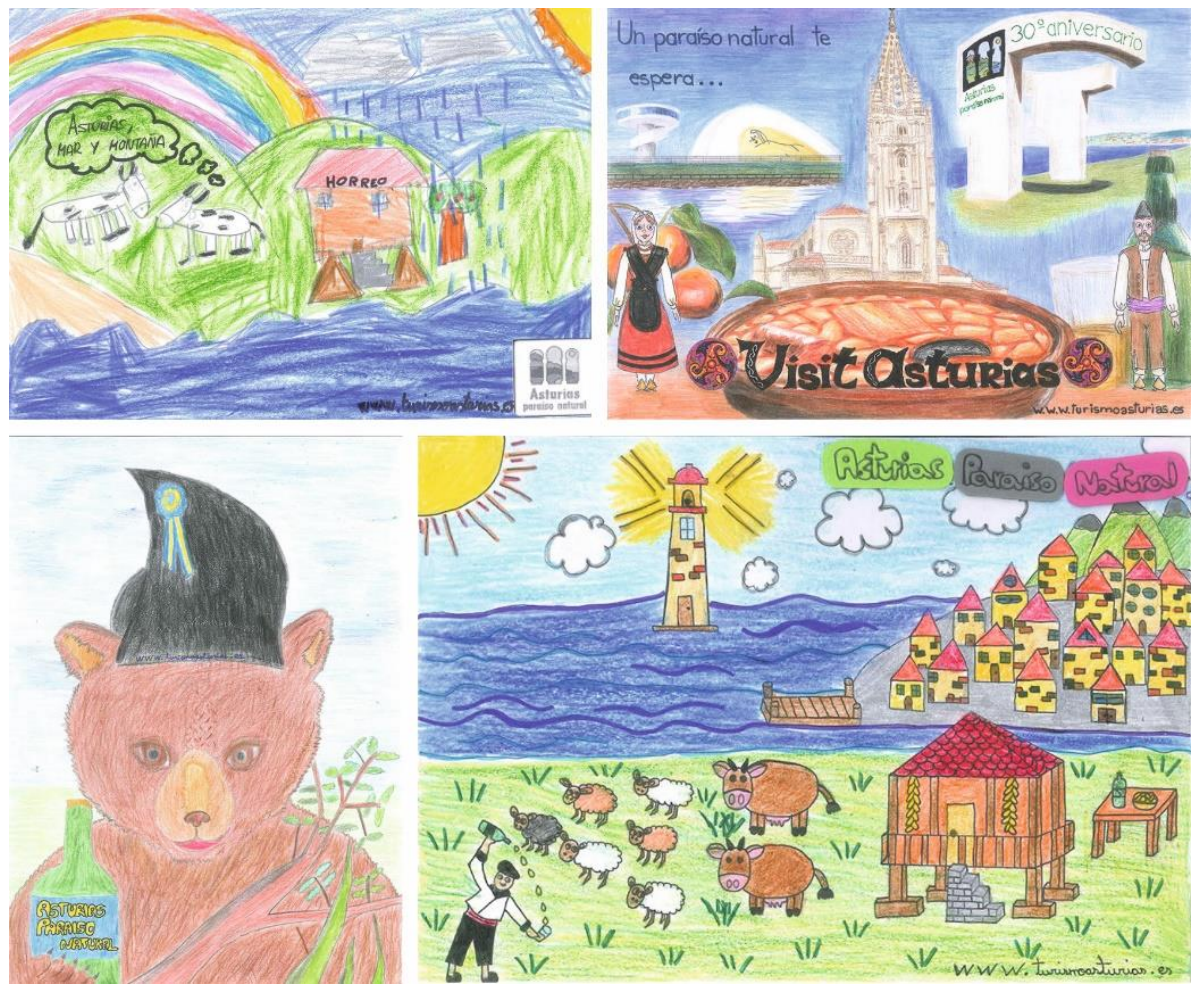

Figure 4. Selection of drawings made by Asturian children for the 2015 drawing contest 'That's how my natural paradise looks like'. 

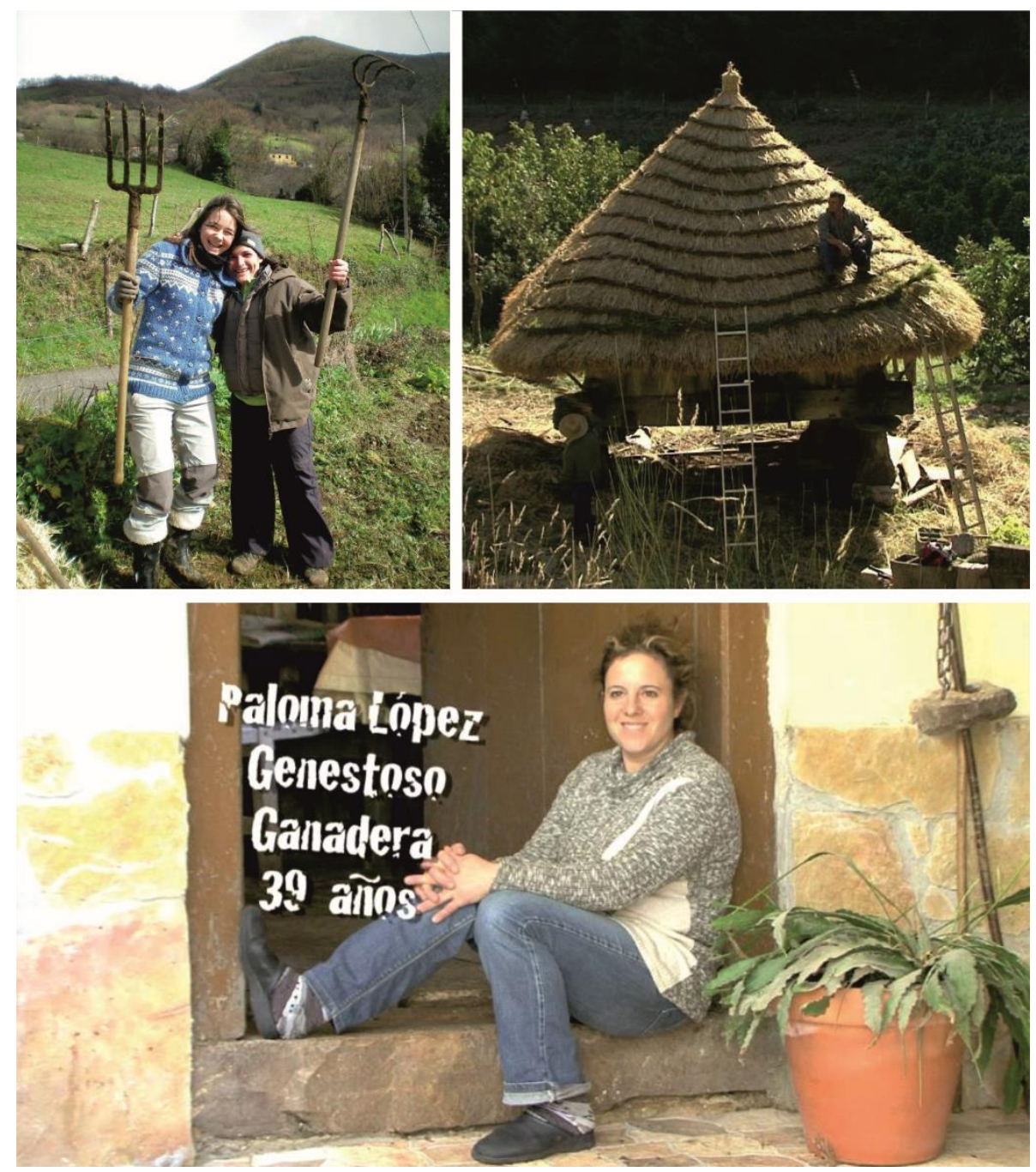

Figure 5. A selection of images shared on the Facebook fanpage 'Guardianes d'Asturies', showing two proud women with their gardening tools (source: Jaime Santos) (top left); two men repairing the thatched straw roof of an elevated wooden granary in Valdeferreiros, Ibias (Asturias) (source: Jaime Santos) (top right); advertisement featuring Paloma López, a 39-years old farmer and an authentic 'Asturian keeper' from Genestoso, Cangas del Narcea (Asturias) (source: Jaime Santos) (bottom).

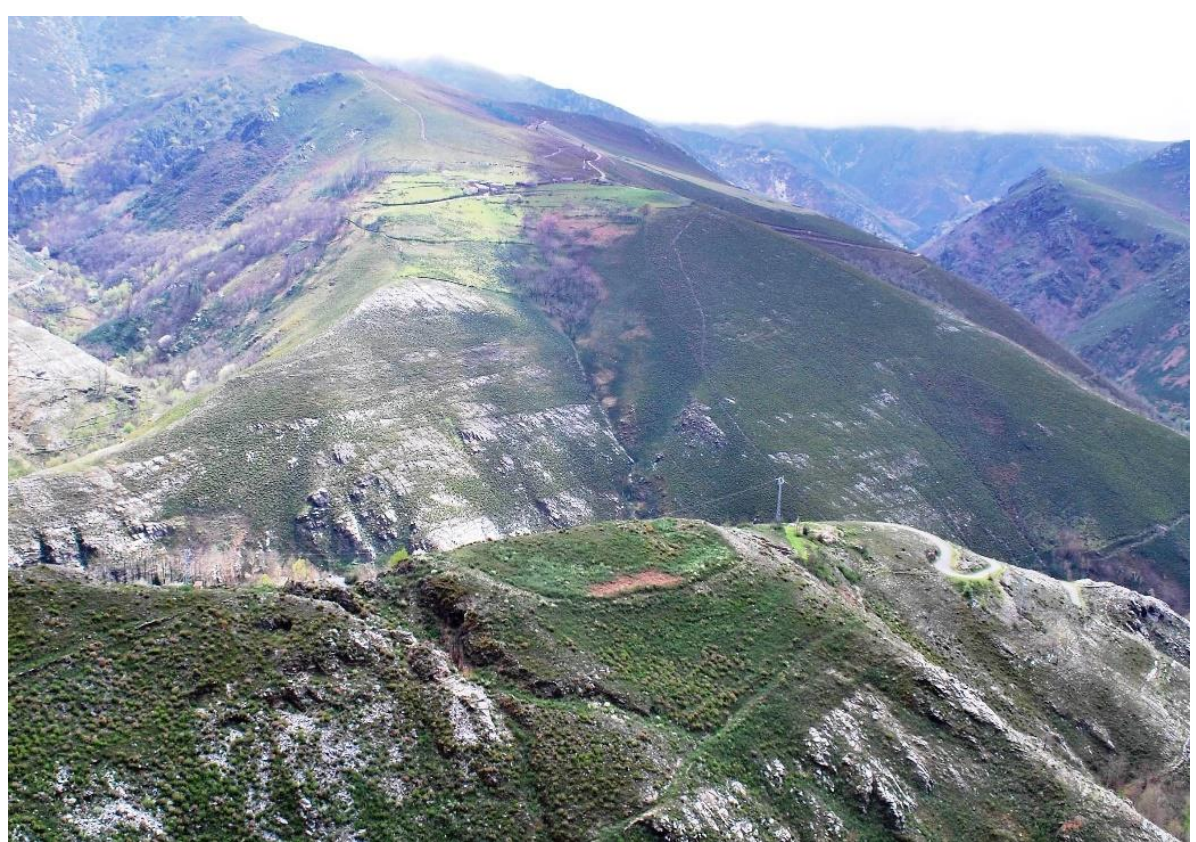

Figure 6. The hillforts constitute the first sedentary settlements in the Cantabrian Mountains, as monumentalised villages which were inhabited by farming communities during the Iron Age. 


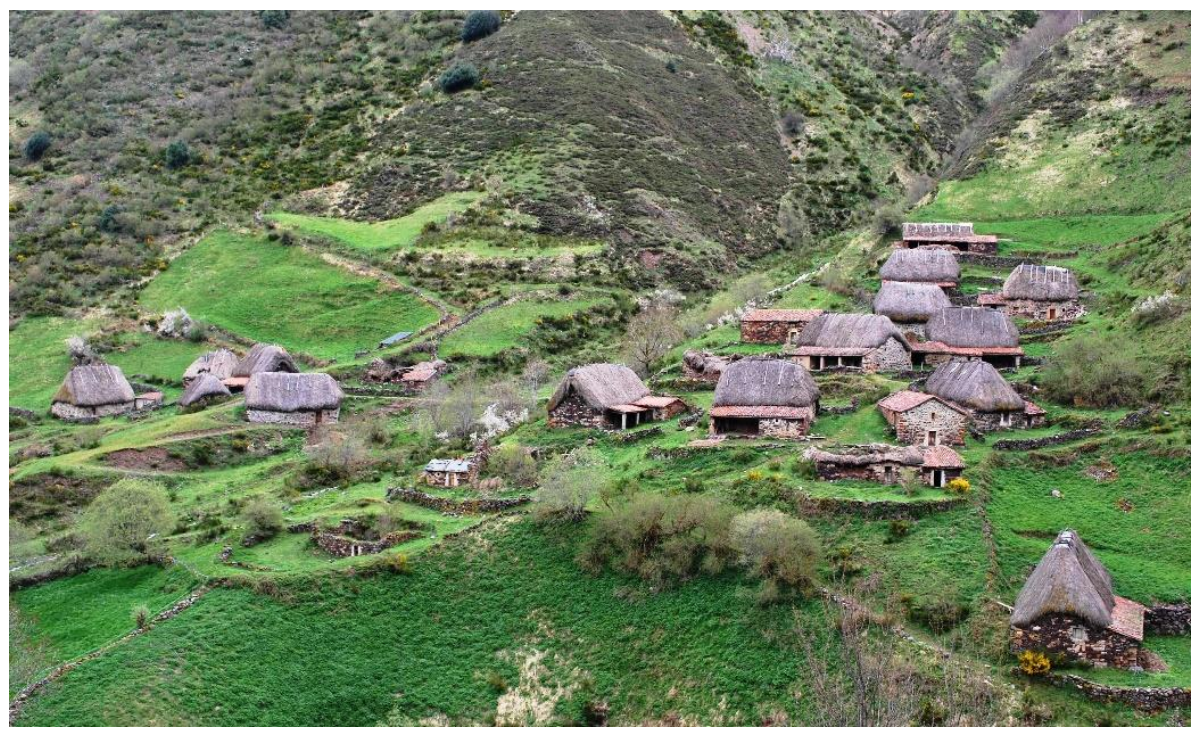

Figure 7. La Pornacal summer farm, in Somiedu (Asturias).
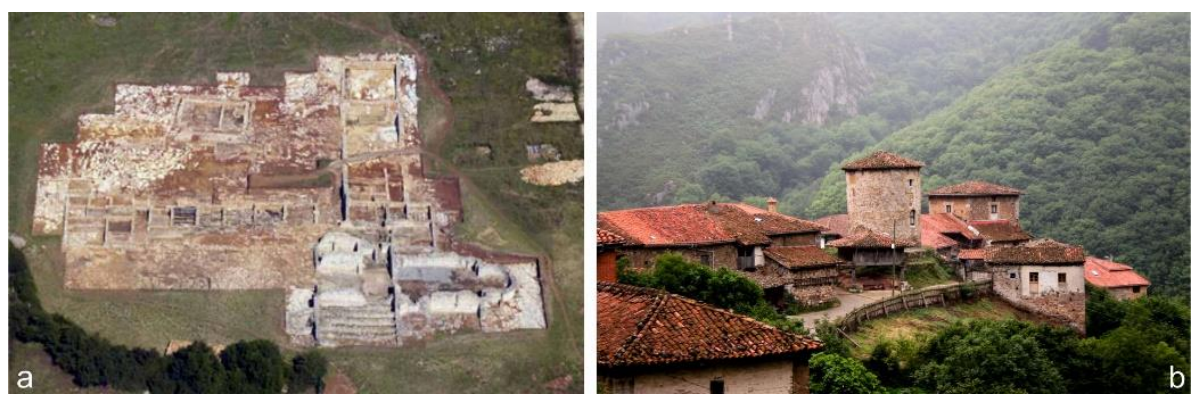

Figure 8. (a) Veranes villa, nearby Gijón (Asturias), is the better preserved archaeological example in Asturias for the rural sites where local aristocracy lived and organised the agrarian landscapes during the Roman period (FernándezOchoa \& Gil-Sendino, 2008); (b) the village of Banduxu, in Proaza (Asturias) has preserved a good image of a medieval village in these mountains with the late medieval Tuñón tower as a prominent materialisation of the power held by local nobility in the medieval political landscapes (source: Jesús Fernández-Fernández).

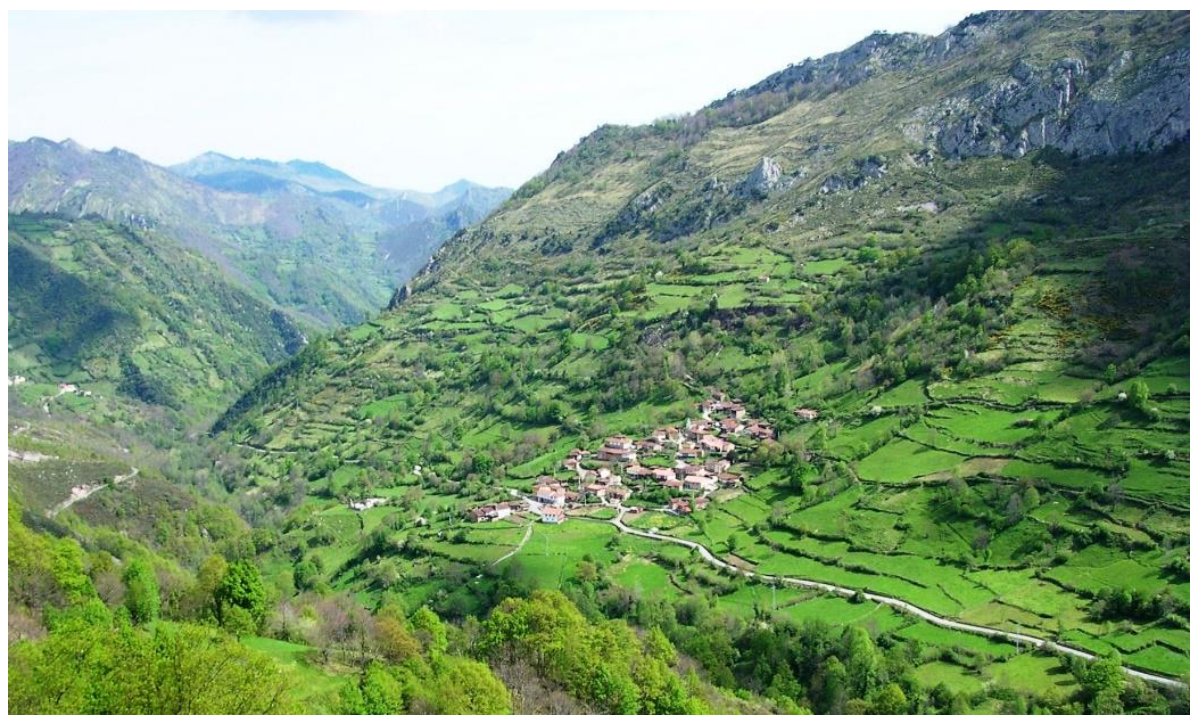

Figure 9. The surroundings of the mountain village of Pigüeña in Somiedu (Asturias) show a typical agrarian fieldsystem around the settlement. The terraced plots that characterise the abandoned fields and meadows are the product of long-term processes and reflect accumulative anthropogenic impact on the landscape which, in this case, probably began in the Late Antiquity, with major changes since the spread of American crops in the modern period. 


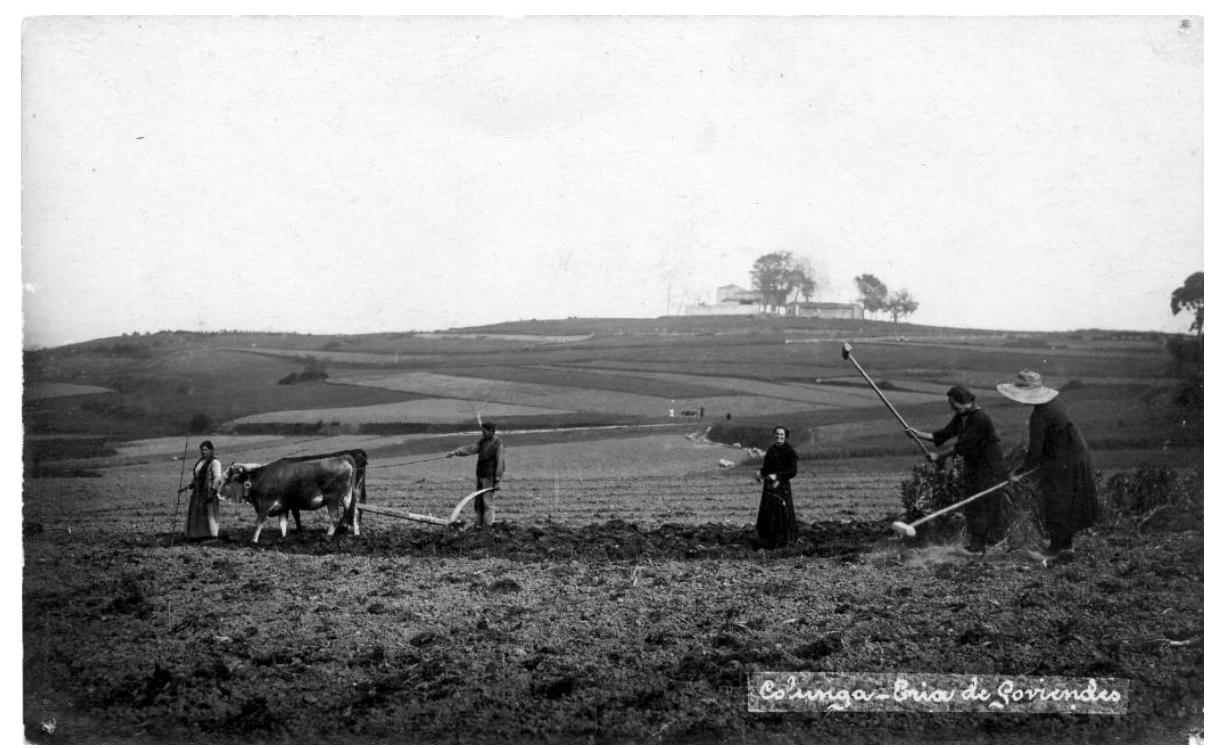

Figure 10. Farmers working the land with a wooden plough pulled by a pair of cows in Gobiendes, Colunga (Asturias), ca. 1920. Notes: Photo by: Emilio Alonso García; photo courtesy of the Muséu del Pueblu d'Asturies 